OPEN ACCESS

Edited by:

Antony Basten,

Garvan Institute of Medical Research,

Australia

Reviewed by:

Kedra Wallace,

University of Mississippi Medical

Center, United States

Nandor Gabor Than,

Hungarian Academy of Sciences

(MTA), Hungary

*Correspondence:

Violeta Stojanovska

violeta.stojanovska@med.ovgu.de

Specialty section:

This article was submitted to Immunological Tolerance and Regulation,

a section of the journal

Frontiers in Immunology

Received: 04 December 2019

Accepted: 24 March 2020

Published: 15 April 2020

Citation:

Stojanovska $V$ and Zenclussen $A C$ (2020) Innate and Adaptive Immune

Responses in HELLP Syndrome.

Front. Immunol. 11:667.

doi: 10.3389/fimmu.2020.00667

\section{Innate and Adaptive Immune Responses in HELLP Syndrome}

\author{
Violeta Stojanovska* and Ana Claudia Zenclussen \\ Experimental Obstetrics and Gynecology, Medical Faculty, Otto von Guericke University Magdeburg, Magdeburg, Germany
}

Innate and adaptive immune involvement in hemolysis, elevated liver enzymes and low platelet (HELLP) syndrome is an understudied field, although it is of high clinical importance. This syndrome implies a risk of serious morbidity and mortality to both the mother and the fetus during pregnancy. It was proposed that HELLP syndrome occurs in a circulatory inflammatory milieu, that might in turn participate in a complex interplay between the secreted inflammatory immunomodulators and immune cell surface receptors. Meanwhile, reported immune cell attenuation during HELLP may consequently lead to a prolonged immunoactivation and tissue damage. In this regard, learning more about the immune components of this syndrome should widen the understanding of the HELLP pathophysiology and eventually enable development of novel immune-based therapeutics. This review aims to summarize and discuss the recent and previous findings of the innate and adaptive immune responses during HELLP in order to update the current knowledge of the immune involvement in HELLP pathogenesis.

Keywords: HELLP, innate immunity, adaptive immunity, complement system, pregnancy

\section{INTRODUCTION}

The maternal immune system has an essential role in pregnancy maintenance and it is furthermore in control of pregnancy development, progression and outcome (1). Pregnancy is a unique physiological state which results in maternal immune tolerance of the developing semi-allogeneic fetus and maternal immune activation in order to induce metabolic adaptation of the mother to meet the increased nutrient demands of the fetus (2). Moreover, a mild systemic inflammatory response is detected in normal pregnancy (3). Tightly controlled interactions between the immune, endocrine, and metabolic system during pregnancy are necessary in order to establish proper placentation, nurture and immune homeostasis $(4,5)$. Disbalance in these interactions is considered to be a base of many pregnancy-associated disorders including Hemolysis, Elevated Liver enzymes, Low Platelet (HELLP) syndrome.

Hemolysis, elevated liver enzymes, low platelet is a life-threatening, rapidly progressive pregnancy-associated disorder that usually occurs in 1-6 women per 1000 pregnancies (6). The clinical symptoms are non-specific and challenging for accurate and fast diagnosis. Two major classification systems (established in the ' $80 \mathrm{~s}$ ) based on laboratory results are used to categorize the patients. In the Tennessee classification, concentrations of lactate dehydrogenase (LDH), aspartate- and alanine-aminotransferase (AST, ALT) and platelet counts are used to assess the degree of hemolysis, liver damage and thrombocytopenia, respectively. With the Mississippi Triple Class System further categorization of the disease is done based on the severity of thrombocytopenia $(7,8)$. Although traditionally HELLP syndrome was considered to be 
a severe form of preeclampsia (a disorder characterized by development of hypertension and proteinuria in pregnancy), several research lines are counteracting to this notion mainly because HELLP is associated with hypertension and/or proteinuria only in $80 \%$ of the cases and shows different cytokine activation and aggravated placental vascular lesions (9-15). Furthermore, the etiopathogenesis of this syndrome is complex and still not completely understood thus, additional and more specific/sensitive laboratory criteria are needed for up-to-date HELLP screening, diagnosis and treatment.

As mentioned, the HELLP syndrome can share some pathophysiological traits with preeclampsia (16). The development of preeclampsia is attributed by deficient spiral artery remodeling and shallow trophoblast invasion. When spiral arteries fail to remodel, either due to inefficient trophoblast invasion and/or inadequate trophoblast induced endothelial cell apoptosis (17), which is primed by immune cells (18), will lead to placental ischemia. This, in turn, is accompanied by an increased release of antiangiogenic factors and activated endothelium that in turn will lead to development of hypertension and proteinuria. In some cases, progress to multiorgan microvascular injury and liver dysfunction then occurs $(16,19)$. In patients with the HELLP syndrome, the fetus can also contribute to initiation of the disease, through abnormal oxidation of fatty acids and transfer of the subsequent metabolic intermediate into the maternal circulation leading to liver and vascular malfunction (20). Interestingly, these changes occur only when the fetus has an inherited metabolic defect in mitochondrial fatty acid oxidation, which is not the case for all HELLP pregnancies. Moreover, HELLP syndrome is associated with leukocytosis (21), and an excessive inflammatory response $(22,23)$ with increased concentrations of proinflammatory and decreased concentrations of anti-inflammatory cytokines $(24,25)$. The fact that corticosteroid administration can halt the progression of the disease (26), suggest that immune system might be involved in the etiopathogenesis of HELLP. In the present review, we aim to compare how the immune system operates during uncomplicated pregnancies and in pregnancies complicated by the HELLP syndrome as reported in the literature. Moreover, we will discuss the detailed aspects of the innate and adaptive immunity by which aberrant activation may predispose the host to hematological and hepatic complications of pregnancy, as seen in HELLP syndrome. In the end, we focus on the currently available experimental models and the possibility for immune-related HELLP research on them.

\section{INNATE IMMUNE COMPONENT IN HELLP}

The innate immune system is the first line of defense against pathogens and it is comprised of cellular and molecular mechanisms that always act in a similar way against infection. All cellular components of the innate immune system have the ability to recognize microbial or damage-associated molecular patterns (known as PAMPs and DAMPs) via pattern recognition receptors (PRRs) or via specific proteins such as the complement system (27). Knowing that in HELLP syndrome several organs are affected and can serve as a source of DAMPs $(28,29)$, it is interesting to know to what extent each of the innate immune components are involved in its etiopathogenesis.

\section{Neutrophils Are Mediators of Liver and Endothelial Damage in HELLP}

Neutrophils are short-lived polymorphonuclear leukocytes that act as effector cells of the innate immunity via phagocytosis, release of cytotoxic enzymes and neutrophil extracellular traps (NETs) and recruitment of other effector cells (30). In addition, neutrophils play a major role in tissue damage and repair (31) by promotion of excessive inflammatory response.

Liver damage is one of the hallmark signs of HELLP syndrome, however, it is still unclear why and how it occurs. The most studied initiator for liver damage so far is the ischemicreperfusion injury. As a consequence of this, hepatocytes show apoptotic and necrotic changes, just as reported in the HELLP syndrome $(32,33)$. As a result of the injury, neutrophil infiltration in the sinusoids and post-sinusoidal venules occurs with concomitant extravasation in the liver parenchyma (34). However, there is a limited evidence about the involvement of neutrophils mediated liver damage in HELLP. In a study from Halim et al. it was reported that liver tissue from HELLP patients was infiltrated with neutrophils in comparison to controls and liver tissue samples from acute fatty liver syndrome patients (35). Another study reported that neutrophils-to-lymphocyte ratio was higher in patients with HELLP syndrome majorly due to increased neutrophils in peripheral blood samples (13). This implicates that in HELLP patients, neutrophil counts are likely increased in the liver and in the peripheral circulation. However, another study reported that neutrophils isolated from peripheral blood from HELLP patients did not show increased reactive oxygen species (ROS) production compared to controls. On the contrary, these neutrophils had diminished ROS production (36), meaning that either these cells show aberrant functionality or were completely exhausted during the course of HELLP. In addition, incubation of neutrophils with sera from HELLP patients show increased ROS production, suggesting that certain factor or factors present in the serum can lead to an increased neutrophil activation (36).

Endothelial activation occurs in HELLP and increased active von Willebrand factor (vWF) levels can contribute to thrombocytopenia in the HELLP syndrome (37). Hulstein et al. hypothesized that the presence of placental debris in the circulation may lead to this activation, which was later proven by Shen et al. that trophoblast debris derived from preeclamptic placentas induced endothelial cell activation (38). Moreover, microparticles derived from placental tissue are able to efficiently activate neutrophils in vitro to generate NETs (39). However, it is not known whether neutrophils infiltration can also lead to endothelial activation in HELLP. Recently, it was reported that NETs can promote endothelial cell activation via IL-1a and cathepsin $\mathrm{G}$ that in turn will lead to an increased thrombogenicity (40), implying that neutrophils might mediate the prothrombotic effect of endothelial activation as registered in HELLP patients. 


\section{Monocytes and Macrophages in HELLP}

Monocytes are short-lived leukocytes that elicit immune responses via phagocytosis, antigen-presentation and cytokine production $(41,42)$. When recruited to a certain tissue, they are capable to differentiate into macrophages or dendritic cells. Macrophages, as terminally differentiated monocytes, are able to induce immune responses in the same way as the monocytes, plus have an additional ability of self-renewal as observed in Hofbauer cells in the placenta and Kupffer cells in the liver (43). In uncomplicated pregnancies, monocyte counts are increased toward the end of the pregnancy and they show functional changes (44), such as increased production of ROS and decreased phagocytic activity and cytokine production (45-47). As the pregnancy progresses, the number of Hofbauer cells changes, showing a peak at the second trimester and gradually declining toward the third trimester (48).

It was reported that during HELLP syndrome the monocyte population is decreased (49) and Hofbauer cells were significantly increased in placentas from HELLP patients, detecting most of the macrophages nearby the vascular area of the villus stroma (50). These opposing findings between normal and HELLP pregnancies suggest that monocytes and macrophages are affected during HELLP syndrome. Moreover, monocytes have the ability to ingest damaged erythrocytes, and via chemotactic signaling they can get accumulated in the liver and be transformed into macrophages responsible for iron turnover (51). Knowing that erythrocyte destruction is increased in HELLP, it would be interesting to know whether this contributes to increased monocyte activation and macrophage overpopulation in the liver. Interestingly, another study confirmed that liver macrophages are responsible for liver damage in an experimental model of HELLP obtained by low dose administration of lipopolysaccharide (52). Treatment with selective inhibitor of macrophages was indeed successful in omitting the symptoms in this experimental model of HELLP (52).

\section{Dendritic Cells in HELLP}

As antigen-presenting cells, dendritic cells (DC) are part of the innate immune system and are able to induce primary immune responses or tolerance (53) by conveying the information toward the adaptive immune system. The dendritic cells can be divided into two subgroups; DC-1 or myeloid dendritic cells which are the largest population in the peripheral blood system and DC2 cells which are lymphoid and can lead the differentiation of $\mathrm{T}$ cells into Th2 cells $(54,55)$. In early pregnancy, the number of DC-1 in peripheral circulation is low, but increases as the pregnancy progresses (55), forming up to $70 \%$ of the total circulating dendritic population (56). Moreover, a shift in dendritic populations can be observed in the presence of different types of cytokines such as IL-4 and TNF-alpha (55). Locally in the placenta, DC are scattered throughout the placental bed in relatively low numbers displaying low proliferative capacities (57), indicating that in the placenta, mostly immature, thus tolerogenic, DC are present. Although the role of DC in fetomaternal tolerance is still unclear, several lines of research propose that DC modulate the maternal immunity toward Th2 type responses in order to maintain the immune tolerance $(58,59)$. Unfortunately, there are not many studies evaluating the number or the functionality of DC in HELLP syndrome. Scholz et al. reported an upregulation and downregulation of certain DC markers in paraffin-embedded placental tissue from HELLP patients (60), whereas these differences were not observed in uncomplicated pregnancies and neither in preeclamptic samples. Since, platelet count and functionality are changed during HELLP syndrome $(6,61)$ and are also involved in proper DC differentiation and activation $(62,63)$, it is important to further evaluate to what extent DC play a role in the immunomodulatory mechanisms of HELLP.

\section{Complement System Involvement in HELLP}

The complement system as part of the innate immune system is comprised of cell bound and free proteins that can interact in a cascade of activation. Complement activation can occur via three pathways depending on the trigger factors including; classical, lectin and alternative pathway (64), resulting in inflammation, cell death or facilitated phagocytosis with consequent clearance of cell debris and pathogens (65). Most of the complement proteins are produced by the hepatocytes (66), however, extrahepatic production was detected as well $(67,68)$. This, in turn, might provide necessary protection against infections in vulnerable tissues. Moreover, the complement system interacts with the coagulation system and can induce platelet activation via C3a and C5a components (69).

Throughout the pregnancy, the complement system does not only protect the organism against infections, but it also orchestrates the optimal placental development (64). In the last third of uncomplicated gestations, several complement components and activation products show higher concentrations in comparison to non-pregnant controls and increased complement activation via the classical and lectin pathway (70). Moreover, several complement components, among which C1q, C3, and C4, are locally produced by cytotrophoblasts and decidual cells $(67,71)$, promoting local defense mechanisms and controlled trophoblast invasion of the placenta. Furthermore, complement deficiencies can lead to aberrant placentation and recurrent pregnancy loss $(72,73)$. Recently, several lines of research attribute the HELLP syndrome as a complementamplifying condition (CAC) $(74,75)$, reinforcing the role of the complement system in its pathogenesis.

Disturbances in the complement components and activity were identified in HELLP patients, although that was not the case in all studies. Screening of HELLP patients in several studies, showed either increased activation of the classical or alternative complement pathway or showed a deficiency of proteins that regulate the complement system (76-79). Moreover, the introduction of immunoglobulin therapy in a limited number of patients with eculizumab, a humanized monoclonal IgG antibody against the complement protein C5, leads to alleviation of the hematological, hepatic and vascular malfunctions that are present in HELLP syndrome $(80,81)$. On the contrary, genetic mutations in the alternative complement 
pathway, although initially proposed as important in mediating HELLP pathogenesis were detected only in a few patients with HELLP $(77,82)$. Another study focusing on the complement $\mathrm{C} 3$ component and regulatory protein complement factor $\mathrm{H}$ in serum from HELLP patients and control subjects showed no changes in the concentrations between the groups (83). Even though the involvement of the complement system in mediating HELLP syndrome is plausible, yet is not as crucial as previously suspected.

\section{Role of NK Cells in HELLP}

Natural killer cells are a group of lymphocytes that have either cytotoxic or cytokine producing properties (84). They get activated based on ligand interaction with the surface activating or inhibitor receptors (85). These receptors are of particular importance in order to prevent the killing of healthy "self" cell. NK cells also produce a variety of chemokines and cytokines, such as; INFg, TNFa, IL-10 and IL-8 $(86,87)$. In the human endometrium and placental bed there is a special population of uterine NK cells (uNK) that are able to produce cytokines, but still are morphologically different than the ones present in peripheral blood, e.g., pbNK (88). This is mainly because they can secrete vascular endothelial growth factor $\mathrm{C}$, placental growth factor (PlGF), angiopoietin 2 (ANG2) and cytokines involved in angiogenesis (89). They are abundant in the first trimester of pregnancy and their number decreases from mid-gestation onward (90). In spite of being part of the innate immune system it was suggested that these cells might act as trained memory cells (91). Besides, uNKs cannot kill.

So far it is known that dysregulation of either peripheral or uterine NK cells is associated with several reproductive conditions, including: infertility, recurrent pregnancy loss and preeclampsia $(89,92)$. To the best of our knowledge, there are no studies reporting or studying the effect of HELLP syndrome on the number or functionality of pbNK or uNK cells. NK cells may however emerge as important in the pathophysiology of HELLP, because they can mediate cell apoptosis via secretion of granzymes, and apoptosis is present in the histopathological data from livers of HELLP patients. Furthermore, platelets interact with NK cells, as known from recent oncological research, either via presenting molecules or antigens such as MHC-1 that can be recognized by the NK cells (93) or via platelet derived ectosomes (94). Knowing that platelets can impair/reduce NK cell reactivity either via ectosomes release and via TGF-b1 signaling, it appears important to understand whether NK cell function is affected when thrombocytes are depleted.

\section{ADAPTIVE IMMUNE COMPONENT IN HELLP}

The adaptive immune system represents the most specialized protection against pathogens and is also characterized by the generation of memory immune cells. The immune response is mediated via two types of responses: the cellular and the humoral response. The cellular one is mediated by $\mathrm{T}$ cells, whereas the humoral one is mediated via production of antibodies produced by the B cells (95). Patients with HELLP syndrome have an increased recurrence risk to develop HELLP syndrome in the next pregnancy as well, although it reappeared in less than $6 \%$ of the subsequent pregnancies $(96,97)$. This implies that the genetic implication of recurrence is subtle and might be dependent on immune system disturbances. Below, we will address what kind of incompetence of $\mathrm{T}$ and $\mathrm{B}$ cells are reported in the HELLP syndrome.

\section{T Cells in HELLP}

$\mathrm{T}$ cells represent a large population of the adaptive immune response and depending on their surface molecules and mode of action, can be subdivided into cytotoxic $\mathrm{T}$ cells (CD8+) and helper $\mathrm{T}$ cells $(\mathrm{CD} 4+)$. CD8+ $\mathrm{T}$ cells directly attack target cells and show immunosuppressive abilities by dampening the production of antibodies by B cells (98). Taken into consideration that CD8+ T cell proliferation increases by the end of pregnancy; they might be involved in the maintenance of fetal tolerance (99). The CD4+ T subset is known for its cytokine production and subsequent activation of macrophages and $\mathrm{B}$ cells. Based on their ability to produce different types of cytokines they can be subdivided into four subgroups; including Th1, Th2, Th17, and Treg cells (100). A delicate balance of Th1/Th2/Th17/Treg is necessary for uncomplicated pregnancy (100).

The pivotal role of Treg cells in developing tolerance in peripheral and transplantation tissues (101), suggested a role for Treg in establishing pregnancy tolerance, a fact that was first described in our laboratory (102). Thus, Treg are thought to prevent pregnancy complications where immune tolerance is affected such as in; infertility, miscarriage and preeclampsia (103-105). Moreover, animal studies showed that Treg depletion leads to an increased proinflammatory status in pregnancy (106) that hindered implantation, altered uterine artery function and increased fetal loss $(102,107)$. Knowing that most studies including samples from patients $(105,108-110)$, but not all $(111,112)$, report reduction in Treg cell expansion during preeclampsia, it is interesting to know whether this is also the case for the HELLP patients. In human studies, it was reported that Treg cell counts and suppressive activity was not affected in patients with HELLP syndrome $(113,114)$. However, the memory $\mathrm{T}$ cell differentiation was altered (115), proposing that the lower number of naive Treg and reinforced differentiation into memory Treg in HELLP patients might preserve their immunosuppressive activity, however, this needs further evaluation.

Animal studies so far propose a more important role for $\mathrm{T}$ cells in HELLP pathogenesis. In an experimental HELLP model obtained by chronic infusion of antiangiogenic factors, it was shown that the overall concentration of CD4+ and CD8+ T cells is increased, while Th17 and Treg concentrations were comparable between the groups $(116,117)$. Later on, when these animals were treated with Abatacept, an antibody that blocks $\mathrm{T}$ cell activation, the biochemical parameters of HELLP syndrome were improved (118). However, the factor(s) leading to an increased $\mathrm{T}$ cell activation in HELLP, remains puzzling. It is interesting to consider that Fas-Fasl system is upregulated in HELLP syndrome (119-121) and one of its multiple roles besides 
promotion of apoptosis is also per se regulation of inflammatory response via activation and proliferation of $\mathrm{CD} 4+$ and $\mathrm{CD} 8+\mathrm{T}$ cells $(122,123)$.

\section{B Cells in HELLP}

$\mathrm{B}$ cells are known to modulate the immune responses by secretion of cytokines, autoantigen presentation and production of antibodies. In short, B cell population can be subclassified into B1, B2 and regulatory B (Breg) cells (124). Whereas B1 and $\mathrm{B} 2$ cell populations have the ability to produce polyreactive and adaptive antibodies, respectively, Breg population possess the ability to secrete IL-10 and IL-35 (125-128). However, a detailed characterization of B cell populations and functionality induced during pregnancy and pregnancy-associated disorders is still limited. Studies in mice revealed that B cell populations are dynamically changed in normal pregnancies by increasing mature $\mathrm{B}$ cells in the bone marrow and the spleen, and decreasing the numbers of pre/pro and immature B cells (125). Moreover, the immunoglobulin levels of $\operatorname{IgM}$, IgA, and IgG in the peripheral circulation are also increased in murine pregnancy in comparison to non-pregnant mice (129). Studies in humans reported that absolute counts of B cell peripheral compartment in the last trimester of pregnancy and in term decidua are decreased in comparison to non-pregnant controls $(130,131)$.

HELLP is not typically described as an autoimmune disorder, however, it is highly prevalent in pregnant women with autoimmune diseases such as acute phospholipid syndrome, systemic lupus erythematosus and thrombotic thrombocytopenic purpura (132-135). To what degree antibodies can play a role in HELLP pathogenesis is still questionable. Previously, it was reported that cytotoxic and antiplatelet antibodies occur in the serum of HELLP patients (136). On the contrary, another study reported that in HELLP patients there are no platelet associated IgGs (137). Considering the wider spectrum of autoantibodies that might be present in pregnancy-associated disorders, Weitgasser et al. reported that $31 \%$ of the HELLP patients have different types of autoantibodies (antinuclear antibodies, anti-thyroid, etc.) in peripheral circulation in comparison to only $10 \%$ in control subjects (138). In animal studies, in an experimental model of HELLP syndrome obtained by anti-angiogenic disbalance it was reported that there was no difference in $\mathrm{B}$ cell counts in the circulation in comparison to a control group (116). However, there is a possibility of $\mathrm{B}$ cell subpopulations number variations and/or altered activation. Our lab reported that B-1a cells contribute to the production of autoantibodies, namely angiotensin II type 1 receptor autoantibodies AT1-AA (139), which were shown to be present in HELLP patients $(26,140,141)$. This served as a background for the development of a novel experimental model of HELLP. When purified IgGs (containing AT1-AA) from HELLP patients and purified IgGs from control subjects were introduced to pregnant rats during mid-gestation, resulted in the development of the biochemical characteristics of HELLP (140). This sheds a light that AT1-AA are involved in the pathogenesis of HELLP, however to what extent and whether there is an interplay with $\mathrm{B}$ and $\mathrm{T}$ cell dysregulation needs further investigation.

\section{CURRENT EXPERIMENTAL MODELS OF HELLP}

Animal models provide the distinctive opportunity to study the immune-related mechanistic traits of HELLP syndrome. Unfortunately, there is no uniform model so far that incorporates all the pathophysiological traits of HELLP. Moreover, most of the available ones were developed as models of preeclampsia $(140,142-144)$ that in the end turned to have exaggerated symptomatology, such as liver dysfunction and hematological abnormalities which are regularly absent in preeclamptic patients. This questions whether all models of preeclampsia in the end can serve as preclinical models of HELLP. In addition, only few have characterized the immunological traits in these models $(52,116)$.

The preeclamptic models so far that were evaluated for liver and hematological abnormalities (Table 1) include the following mechanisms of action; systemic inflammation (52), angiogenic disbalance (116), transfer of autoantibodies (140, 143), affected low oxygen sensing (144) and the combined model of angiogenic disbalance and impaired nitric oxide production (145). On the contrary, the model of reduced uterine perfusion pressure (RUPP) which is regularly used for preeclampsia research, does not show the biochemical characteristics of HELLP (146). Thus far, only the initial inflammation model of preeclampsia (147), was adjusted to mirror HELLP characteristics (52). Late gestation administration of 200 times higher LPS concentrations in rats resulted in laboratory and histological abnormalities, as registered in HELLP patients, including thrombocytopenia, hemolysis, elevated liver enzymes, hepatocellular necrosis, sinusoidal fibrin deposits and increased macrophage liver infiltration. Almost all symptomatology, except fetal loss, was reversed when the animals were pretreated with gadolinium III chloride which serves as selective macrophage inhibitor, proposing that indeed maternal immunological alterations can mediate HELLP pathogenesis (52). Arguably, although all animal models in one way or another depict the clinical characteristics of HELLP, still it remains uncertain whether the entire sequence of pathophysiological events is fully represented including the immunological disturbances as observed in HELLP patients.

Treatment strategies for HELLP syndrome can also have a detrimental effect on the immune system and can be easily tested in vivo. However, this area is scarcely reported in the literature to date. For instance, in a meta-analysis of total of fifteen studies it was concluded that corticosteroids significantly prevent the platelet consumption and erythrocyte destruction (148) without tackling down the effect on the immune cells. It is a similar situation with the eculizumab treatment for HELLP syndrome. The study from Elabd et al. (81) shows that platelets, white blood cells counts and hepatological parameters are improved in HELLP patients, but detailed analysis of the effect on immune cells 
TABLE 1 | Overview of the current experimental animal models of hemolysis, elevated liver enzymes and low platelets (HELLP) syndrome.

\begin{tabular}{|c|c|c|c|c|c|}
\hline Mechanism of action & Strain & Method & HELLP traits & Immune responses & References \\
\hline Inflammation & SD rats & GD 17 & $\uparrow A S T$, ALT and LDH & Macrophage infiltration in & (52) \\
\hline & & $\begin{array}{l}\text { Systemic i.v. administration } \\
\text { of } 0.2 \mathrm{mg} / \mathrm{kg} \text { LPS }\end{array}$ & $\begin{array}{l}\downarrow \text { platelets } \\
\text { Liver necrosis, fibrin } \\
\text { deposits }\end{array}$ & the liver & \\
\hline \multirow{4}{*}{$\begin{array}{l}\text { Angiogenic } \\
\text { disbalance }\end{array}$} & \multirow[t]{4}{*}{$\mathrm{SD}$ rats } & \multirow{4}{*}{$\begin{array}{l}\text { GD 12-19 } \\
\text { i.p. chronic administration } \\
\text { of recombinant sFlt-1 and } \\
\text { sEng via osmotic pumps }\end{array}$} & $\uparrow A L T, L D H$ & 个TNFa, IL-6, IL-17 & $(116)$ \\
\hline & & & \multirow[t]{3}{*}{$\downarrow$ platelets } & $\begin{array}{l}\uparrow \mathrm{CD} 8+\mathrm{T} \text { cells in circulation } \\
\text { and liver }\end{array}$ & \\
\hline & & & & $\begin{array}{l}\uparrow \mathrm{CD} 4+\mathrm{T} \text { cells in } \\
\text { circulation, liver and } \\
\text { placenta }\end{array}$ & \\
\hline & & & & $\begin{array}{l}\downarrow \text { Treg/Th17 ratio in } \\
\text { circulation and liver }\end{array}$ & \\
\hline Autoantibodies & SD rats & GD 10 & $\uparrow A L T, L D H$ & Plasma $\uparrow \mathrm{TNFa}$ & $(140)$ \\
\hline transfer & & $\begin{array}{l}\text { i.v. IgG (containing AT1-AA) } \\
\text { transfer }\end{array}$ & $\begin{array}{l}\downarrow \text { platelets } \\
\text { Liver necrosis }\end{array}$ & $\begin{array}{l}\text { Limited lymphocyte } \\
\text { infiltration in the liver }\end{array}$ & \\
\hline $\begin{array}{l}\text { Low oxygen sensing } \\
\text { disruption }\end{array}$ & C57BI/6J mice & $\begin{array}{l}\text { GD } 8 \\
\text { Adenoviral overexpression } \\
\text { of HIF-1a }\end{array}$ & $\begin{array}{l}\uparrow A S T, \text { ALT, LDH } \\
\downarrow \text { platelets } \\
\text { Fibrin deposits in the liver }\end{array}$ & $\begin{array}{l}\text { Lymphocyte infiltration in } \\
\text { the liver }\end{array}$ & $(144)$ \\
\hline $\begin{array}{l}\text { Angiogenic imbalance } \\
\text { and impaired NO } \\
\text { production }\end{array}$ & C57Bl/6J mice & $\begin{array}{l}\text { Adenoviral overexpression } \\
\text { of sFlt-1in non-pregnant } \\
\text { endothelial NOS }-/- \text { mice } \\
\text { These animals cannot } \\
\text { maintain pregnancy }\end{array}$ & $\begin{array}{l}\uparrow A S T, \text { ALT } \\
\downarrow \text { platelet } \\
\text { No changes in erythrocyte } \\
\text { counts } \\
\text { Liver necrosis and } \\
\text { apoptosis, fibrin deposits }\end{array}$ & $\begin{array}{l}\text { Neutrophil infiltration in the } \\
\text { liver }\end{array}$ & $(145)$ \\
\hline
\end{tabular}

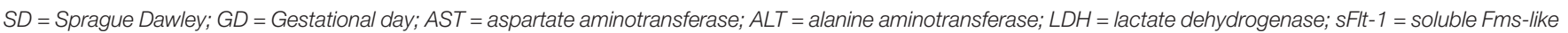

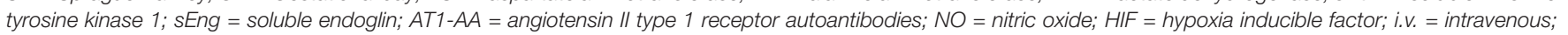
i.p. = intraperitoneal.

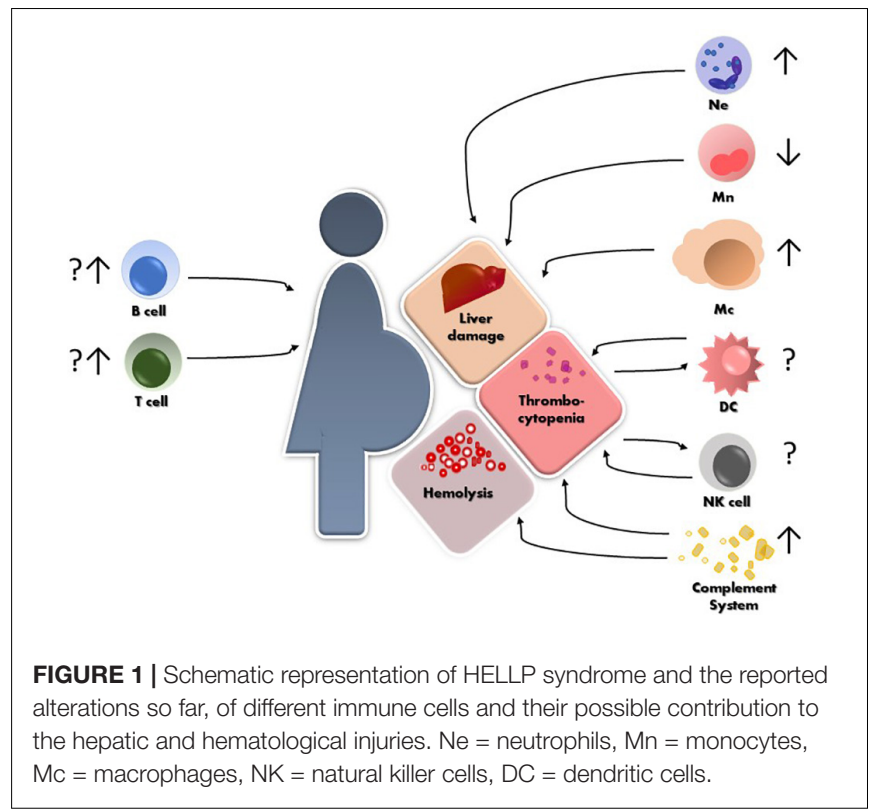

is missing. Knowing that potential treatments for HELLP syndrome are limited, identification of an appropriate one that will consider the whole pathophysiological feature is of major importance.

\section{CONCLUDING REMARKS AND FUTURE PROSPECTS}

The maternal immune system plays a critical role in several aspects of pregnancy, from defense against pathogens, through establishment of a suitable immune milieu for embryo implantation and placentation to specific tolerance of paternally derived antigens. We are just beginning to understand to what grade the immune system plays a role in the development of HELLP. What we have summarized in this review is that isolated reports cover all segments of the immune system as being in one way or another involved in the pathogenesis and the clinical course of HELLP (Figure 1). However, more conclusive data are necessary in order to unravel which factor precedes the other and what is the correct interplay that leads to the development of HELLP. Most importantly, working in vitro, ex vivo and in vivo models are necessary to tackle down the maternal or fetal component(s) that initiate the cascade of events leading to HELLP.

Taking into account that HELLP syndrome is a rare disorder and that all of the studies face the same limitation, such as having a small cohort studies, multicenter collaborations, a large multicentric cohort study ("big data") might overcome this problem in future. Moreover, developing a specific translational experimental model of HELLP that can provide extensive inside into the immunomodulatory mechanisms underlining the 
syndrome is of vital importance. Proper identification of the immune disturbances and strategies to target the same, can ensure additional diagnostic and therapeutic perspectives for the HELLP syndrome.

\section{REFERENCES}

1. Schumacher A, Sharkey DJ, Robertson SA, Zenclussen AC. Immune cells at the fetomaternal interface: how the microenvironment modulates immune cells to foster fetal development. J Immunol. (2018) 201:325-34. doi: 10.4049/ jimmunol.1800058

2. Herrera E. Lipid metabolism in pregnancy and its consequences in the fetus and newborn. Endocrine. (2002) 19:43-55. doi: 10.1385/ENDO:19:1:43

3. Palm M, Axelsson O, Wernroth L, Larsson A, Basu S. Involvement of inflammation in normal pregnancy. Acta Obstet Gynecol Scand. (2013) 92:601-5. doi: 10.1111/aogs.12093

4. Zmora N, Bashiardes S, Levy M, Elinav E. The role of the immune system in metabolic health and disease. Cell Metab. (2017) 25:506-21. doi: 10.1016/j. cmet.2017.02.006

5. Schumacher A, Costa SD, Zenclussen AC. Endocrine factors modulating immune responses in pregnancy. Front Immunol. (2014) 5:1-12. doi: 10. 3389/fimmu.2014.00196

6. Haram K, Svendsen E, Abildgaard U. The HELLP syndrome: Clinical issues and management. A review. BMC Pregnancy Childbirth. (2009) 9:1-15. doi: 10.1186/1471-2393-9-8

7. Aloizos S, Seretis C, Liakos N, Aravosita P, Mystakelli C, Kanna E, et al. syndrome: understanding and management of a pregnancy-specific disease. J Obstet Gynaecol (Lahore). (2013) 33:331-7. doi: 10.3109/01443615.2013. 775231

8. Rimaitis K, Grauslyte L, Zavackiene A, Baliuliene V, Nadisauskiene R, Macas A. Diagnosis of HELLP syndrome: a 10-year survey in a perinatology centre. Int J Environ Res Public Health. (2019) 16:1-9. doi: 10.3390/ijerph16010109

9. Sibai BM, Taslimi MM, El-Nazer A, Amon E, Mabie BC, Ryan GM. Maternalperinatal outcome associated with the syndrome of hemolysis, elevated liver enzymes, and low platelets in severe preeclampsia-eclampsia. Am J Obstet Gynecol. (1986) 155:501-7. doi: 10.1016/0002-9378(86)90266-8

10. Sibai BM. Diagnosis, controversies, and management of the syndrome of hemolysis, elevated liver enzymes, and low platelet count. Obstet Gynecol. (2004) 103:981-91. doi: 10.1097/01.AOG.0000126245.35811.2a

11. Lachmeijer AMA, Arngrímsson R, Bastiaans EJ, Frigge ML, Pals G, Sigurdardóttir S, et al. A genome-wide scan for preeclampsia in the Netherlands. Eur J Hum Genet. (2001) 9:758-64. doi: 10.1038/sj.ejhg. 5200706

12. Weiner E, Schreiber L, Grinstein E, Feldstein O, Rymer-Haskel N, Bar J, et al. The placental component and obstetric outcome in severe preeclampsia with and without HELLP syndrome. Placenta. (2016) 47:99-104. doi: 10.1016/j. placenta.2016.09.012

13. Sisti G, Faraci A, Silva J, Upadhyay R. Neutrophil-to-lymphocyte ratio, platelet-to-lymphocyte ratio, and routine complete blood count components in HELLP syndrome: a matched case control study. Medicina (B Aires). (2019) 55:123. doi: 10.3390/medicina55050123

14. Várkonyi T, Nagy B, Füle T, Tarca AL, Karászi K, Schönléber J, et al. Microarray profiling reveals that placental transcriptomes of early-onset HELLP syndrome and preeclampsia are similar. Placenta. (2011) 32:s21-9. doi: 10.1016/j.placenta.2010.04.014

15. Szabo S, Mody M, Romero R, Xu Y, Karaszi K, Mihalik N, et al. Activation of villous trophoblastic p38 and ERK1/2 signaling pathways in preterm preeclampsia and HELLP syndrome. Pathol Oncol Res. (2015) 21:659-68. doi: $10.1007 /$ s12253-014-9872-9

16. Abildgaard U, Heimdal K. Pathogenesis of the syndrome of hemolysis, elevated liver enzymes, and low platelet count (HELLP): a review. Eur J Obstet Gynecol Reprod Biol. (2013) 166:117-23. doi: 10.1016/j.ejogrb.2012. 09.026

17. Whitley GSJ, Cartwright JE. Trophoblast-mediated spiral artery remodelling: a role for apoptosis. J Anat. (2009) 215:21-6. doi: 10.1111/j.1469-7580.2008. 01039.x

\section{AUTHOR CONTRIBUTIONS}

VS wrote the manuscript and prepared the figure and table. AZ provided critical feedback.

18. Meyer N, Woidacki K, Knöfler M, Meinhardt G, Nowak D, Velicky P, et al. Chymase-producing cells of the innate immune system are required for decidual vascular remodeling and fetal growth. Sci Rep. (2017) 7:1-14. doi: 10.1038/srep45106

19. Andraweera PH, Dekker GA, Roberts CT. The vascular endothelial growth factor family in adverse pregnancy outcomes. Hum Reprod Update. (2012) 18:436-57. doi: 10.1093/humupd/dms011

20. Shekhawat PS, Matern D, Strauss AW. Fetal fatty acid oxidation disorders, their effect on maternal health and neonatal outcome: impact of expanded newborn screening on their diagnosis and management. Pediatr Res. (2005) 57:78R-86R. doi: 10.1203/01.PDR.0000159631.63843.3E

21. Terrone DA, Rinehart BK, May WL, Moore A, Magann EF, Martin JNJ. Leukocytosis is proportional to HELLP syndrome severity: evidence for an inflammatory form of preeclampsia. South Med J. (2000) 93:768-71. doi: 10.1097/00006254-200104000-00002

22. Van Runnard Heimel PJ, Kavelaars A, Heijnen CJ, Peters WHM, Huisjes AJM, Franx A, et al. syndrome is associated with an increased inflammatory response, which may be inhibited by administration of prednisolone. Hypertens Pregnancy. (2008) 27:253-65. doi: 10.1080/10641950802174953

23. Simsek Y, Gul M, Celik O, Aydin NE, Arda Düz S, Celik E, et al. Nuclear transcription factor-kappa beta-dependent ultrastructural alterations within the placenta and systemic inflammatory activation in pregnant patients with hemolysis, elevated liver functions and low thrombocyte count (HELLP) syndrome: a case-control. Hypertens Pregnancy. (2013) 32:281-91. doi: 10. 3109/10641955.2013.806538

24. Xie F, von Dadelszen P, Nadeau J. CMV Infection, TLR-2 and -4 Expression, and Cytokine Profiles in Early-Onset Preeclampsia with HELLP syndrome. Am J Reprod Immunol. (2014) 71:379-86. doi: 10.1111/aji.12199

25. Tranquilli AL, Landi B, Corradetti A, Giannubilo SR, Sartini D, Pozzi V, et al. Inflammatory cytokines patterns in the placenta of pregnancies complicated by HELLP (hemolysis, elevated liver enzyme, and low platelet) syndrome. Cytokine. (2007) 40:82-8. doi: 10.1016/j.cyto.2007.08.010

26. Wallace K, Martin JN, Tam Tam K, Wallukat G, Dechend R, Lamarca B, et al. Seeking the mechanism(s) of action for corticosteroids in HELLP syndrome: SMASH study. Am J Obstet Gynecol. (2013) 208:.e1-380. doi: 10.1016/j.ajog. 2013.01.049

27. Amarante-Mendes GP, Adjemian S, Branco LM, Zanetti LC, Weinlich R, Bortoluci KR. Pattern recognition receptors and the host cell death molecular machinery. Front Immunol. (2018) 9:1-19. doi: 10.3389/fimmu.2018.02379

28. Brien M-E, Baker B, Duval C, Gaudreault V, Jones RL, Girard S. Alarmins at the maternal-fetal interface: involvement of inflammation in placental dysfunction and pregnancy complications. Can J Physiol Pharmacol. (2018) 97:206-12. doi: 10.1139/cjpp-2018-0363

29. Nadeau-Vallée M, Obari D, Palacios J, Brien MẼ, Duval C, Chemtob S, et al. Sterile inflammation and pregnancy complications: a review. Reproduction. (2016) 152:R277-92. doi: 10.1530/REP-16-0453

30. Mócsai A. Diverse novel functions of neutrophils in immunity, infammation, and beyond. J Exp Med. (2013) 210:1289-99. doi: 10.1084/jem.2012 2220

31. Selders GS, Fetz AE, Radic MZ, Bowlin GL. An overview of the role of neutrophils in innate immunity, inflammation and host-biomaterial integration. Regen Biomater. (2017) 4:55-68. doi: 10.1093/rb/rbw041

32. John K, Wielgosz S, Schulze-Osthoff K, Bantel H, Hass R. Increased plasma levels of CK-18 as potential cell death biomarker in patients with HELLP syndrome. Cell Death Dis. (2013) 4:e886-885. doi: 10.1038/cddis.2013.408

33. Hammoud GM, Ibdah JA. Preeclampsia-induced Liver Dysfunction, HELLP syndrome, and acute fatty liver of pregnancy. Clin Liver Dis. (2014) 4:69-73. doi: 10.1002/cld.409

34. Ramaiah SK, Jaeschke H. Role of neutrophils in the pathogenesis of acute inflammatory liver injury. Toxicol Pathol. (2007) 35:757-66. doi: 10.1080/ 01926230701584163 
35. Halim A, Kanayama N, Marradny EE, Maehara K, Takahashi A, Nosaka K, et al. Immunohistological study in cases of HELLP syndrrome (hemolysis, elevated liver enzymes and low platelets) and acute fatty liver of pregnancy. Gynecol Obstet Invest. (1996) 41:106-12.

36. Zusterzeel PLM, Wanten GJA, Peters WHM, Merkus HMWM, Steegers EAP. Neutrophil oxygen radical production in pre-eclampsia with HELLP syndrome. Eur J Obstet Gynecol Reprod Biol. (2001) 99:213-8. doi: 10.1016/ S0301-2115(01)00377-3

37. Hulstein JJJ, Van Runnard Heimel PJ, Franx A, Lenting PJ, Bruinse HW, Silence $\mathrm{K}$, et al. Acute activation of the endothelium results in increased levels of active von Willebrand factor in hemolysis, elevated liver enzymes and low platelets (HELLP) syndrome. J Thromb Haemost. (2006) 4:2569-75. doi: 10.1111/j.1538-7836.2006.02205.x

38. Shen F, Wei J, Snowise S, DeSousa J, Stone P, Viall C, et al. Trophoblast debris extruded from preeclamptic placentae activates endothelial cells: a mechanism by which the placenta communicates with the maternal endothelium. Placenta. (2014) 35:839-47. doi: 10.1016/j.placenta.2014.07. 009

39. Gupta AK, Hasler P, Holzgreve W, Hahn S. Neutrophil NETs: a novel contributor to preeclampsia-associated placental hypoxia? Semin Immunopathol. (2007) 29:163-7. doi: 10.1007/s00281-007-0073-4

40. Folco EJ, Mawson TL, Vromman A, Bernardes-Souza B, Franck G, Persson $\mathrm{O}$, et al. Neutrophil extracellular traps induce endothelial cell activation and tissue factor production through interleukin-1 $\alpha$ and cathepsin G. Arterioscler Thromb Vasc Biol. (2018) 38:1901-12. doi: 10.1161/ATVBAHA.118.311150

41. Ogle ME, Segar CE, Sridhar S, Botchwey EA. Monocytes and macrophages in tissue repair: implications for immunoregenerative biomaterial design. Exp Biol Med. (2016) 241:1084-97. doi: 10.1177/1535370216650293

42. Chiu S, Bharat A. Role of monocytes and macrophages in regulating immune response following lung transplantation. Curr Opin Organ Transplant. (2016) 21:239-45. doi: 10.1097/MOT.0000000000000313

43. Hashimoto D, Chow A, Noizat C, Teo P, Beth M, Leboeuf M, et al. Adult life with minimal contribution from circulating monocytes. Immunity. (2013) 38:1-25. doi: 10.1016/j.immuni.2013.04.004

44. Faas MM, de Vos P. Maternal monocytes in pregnancy and preeclampsia in humans and in rats. J Reprod Immunol. (2017) 119:91-7. doi: 10.1016/j.jri. 2016.06.009

45. Sacks GP, Studena K, Sargent IL, Redman CWG. Normal pregnancy and preeclampsia both produce inflammatory changes in peripheral blood leukocytes akin to those of sepsis. Am J Obstet Gynecol. (1998) 179:80-6. doi: 10.1016/S0002-9378(98)70254-6

46. Lampé R, Kövér Á, Szucs S, Pál L, Árnyas E, Ádány R, et al. Phagocytic index of neutrophil granulocytes and monocytes in healthy and preeclamptic pregnancy. J Reprod Immunol. (2015) 107:26-30. doi: 10.1016/j.jri.2014.11. 001

47. Veenstra Van Nieuwenhoven AL, Bouman A, Moes H, Heineman MJ, De Leij LFMH, Santema J, et al. Endotoxin-induced cytokine production of monocytes of third-trimester pregnant women compared with women in the follicular phase of the menstrual cycle. Am J Obstet Gynecol. (2003) 188:1073-7. doi: 10.1067/mob.2003.263

48. Vinnars MTN, Rindsjö E, Ghazi S, Sundberg A, Papadogiannakis N. The number of CD68+ (Hofbauer) cells is decreased in placentas with chorioamnionitis and with advancing gestational age. Pediatr Dev Pathol. (2010) 13:300-4. doi: 10.2350/09-03-0632-OA.1

49. Cunningham D, Christie T, Evans E, McCaul J. Effect of the HELLP syndrome on maternal immune function. J Reprod Med Obstet Gynecol. (1993) 38:459-64.

50. Evsen MS, Kalkanli S, Deveci E, Sak ME, Ozler A, Baran Ö, et al. Human placental macrophages (Hofbauer cells) in severe preeclampsia complicated by HELLP syndrome. Anal Quant. Cytol Histol (2013) 35:283-8.

51. Theurl I, Hilgendorf I, Nairz M, Tymoszuk P, Asshoff M, He S, et al. Transient macrophages in the liver. Nat Med. (2017) 22:945-51. doi: 10.1038/nm.4146

52. Nakamura H, Umesaki N, Ogita S, Kaneda K. Administration of low-dose lipopolysaccharide induces HELLP-like syndrome (hemolysis, elevated liver enzymes and low platelets) in pregnant rats: Involvement of macrophages in its pathogenesis. Biomed Res. (1997) 18:65-73. doi: 10.2220/biomedres.18.65

53. Hasegawa $\mathrm{H}$, Matsumoto T. Mechanisms of tolerance induction by dendritic cells in vivo. Front Immunol. (2018) 9:350. doi: 10.3389/fimmu.2018.00350
54. Banchereau J, Briere F, Caux C, Davoust J, Lebecque S, Liu Y, et al. Immunobiologgy of dendritic cells. Annu Rev Immunol. (2000) 18:767-811. doi: 10.1146/annurev.immunol.18.1.767

55. Darmochwal-Kolarz D, Rolinski J, Tabarkiewicz J, Leszczynska-Gorzelak B, Buczkowski J, Wojas K, et al. Myeloid and lymphoid dendritic cells in normal pregnancy and pre-eclampsia. Clin Exp Immunol. (2003) 132:339-44. doi: 10.1046/j.1365-2249.2003.02136.x

56. Bachy V, Williams DJ, Ibrahim MAA. Altered dendritic cell function in normal pregnancy. J Reprod Immunol. (2008) 78:11-21. doi: 10.1016/j.jri. 2007.09.004

57. Rieger L, Honig A, Sütterlin M, Kapp M, Dietl J, Ruck P, et al. Antigenpresenting cells in human endometrium during the menstrual cycle compared to early pregnancy. J Soc Gynecol Investig. (2004) 11:488-93. doi: 10.1016/j.jsgi.2004.05.007

58. Miyazaki S, Tsuda H, Sakai M, Hori S, Sasaki Y. Predominance of Th2promoting dendritic cells in early human pregnancy decidua antigenpresenting cells required for the priming tiation of nat. J Leukoc Biol. (2003) 74:514-22. doi: 10.1189/jlb.1102566.1

59. Gorvel L, Ben Amara A, Mignane Biram KA, Textoris J, Gorvel JP, Mege JL. Myeloid decidual dendritic cells and immunoregulation of pregnancy: defective responsiveness to Coxiella burnetii and Brucella abortus. Front Cell Infect Microbiol. (2014) 4:1-10. doi: 10.3389/fcimb.2014.00179

60. Scholz C, Toth B, Santoso L, Kuhn C, Franz M, Mayr D, et al. Distribution and maturity of dendritic cells in diseases of insufficient placentation. Am J Reprod Immunol. (2008) 60:238-45. doi: 10.1111/j.1600-0897.2008.00619.x

61. Kuiper GJAJM, Lancé MD, Smit-Fun VM, Peeters LLH, Marcus MAE. Platelet monitoring follow-up in a pregnant patient with HELLP syndrome. Platelets. (2011) 22:160-3. doi: 10.3109/09537104.2010.528088

62. Kissel K, Berber S, Nockher A, Santoso S, Bein G, Hackstein H. Human platelets target dendritic cell differentiation and production of proinflammatory cytokines. Transfusion. (2006) 46:818-27. doi: 10.1111/j. 1537-2995.2006.00802.x

63. Hamzeh-Cognasse H, Cognasse F, Palle S, Chavarin P, Olivier T, Delézay O, et al. Direct contact of platelets and their released products exert different effects on human dendritic cell maturation. BMC Immunol. (2008) 9:54. doi: 10.1186/1471-2172-9-54

64. Regal JF, Gilbert JS, Burwick RM. The complement system and adverse pregnancy outcomes jean. Mol Immunol. (2015) 67:56-70. doi: 10.1016/j. molimm.2015.02.030

65. Ricklin D, Reis ES, Lambris JD. Complement in disease: a defence system turning offensive. Nat Rev Nephrol. (2016) 12:383-401. doi: 10.1038/nrneph. 2016.70

66. Zhou Z, Xu MJ, Gao B. Hepatocytes: a key cell type for innate immunity. Cell Mol Immunol. (2016) 13:301-15. doi: 10.1038/cmi.2015.97

67. Bulla R, Bossi F, Agostinis C, Radillo O, Colombo F, De Seta F, et al. Complement production by trophoblast cells at the feto-maternal interface. $J$ Reprod Immunol. (2009) 82:119-25. doi: 10.1016/j.jri.2009.06.124

68. Lubbers R, van Essen MF, van Kooten C, Trouw LA. Production of complement components by cells of the immune system. Clin Exp Immunol. (2017) 188:183-94. doi: 10.1111/cei.12952

69. Peerschke EI, Yin W, Ghebrehiwet B. Complement activation on platelets: implications for vascular inflammation and thrombosis. Mol Immunol. (2010) 47:2170-5. doi: 10.1016/j.molimm.2010.05.009

70. Derzsy Z, Prohászka Z, Rigó J, Füst G, Molvarec A. Activation of the complement system in normal pregnancy and preeclampsia. Mol Immunol. (2010) 47:1500-6. doi: 10.1016/j.molimm.2010.01.021

71. Bulla R, Agostinis C, Bossi F, Rizzi L, Debeus A, Tripodo C, et al. Decidual endothelial cells express surface-bound $\mathrm{C} 1 \mathrm{q}$ as a molecular bridge between endovascular trophoblast and decidual endothelium. Mol Immunol. (2008) 45:2629-40. doi: 10.1016/j.molimm.2007.12.025

72. Agostinis C, Bulla R, Tripodo C, Gismondi A, Stabile H, Bossi F, et al. An alternative role of $\mathrm{Clq}$ in cell migration and tissue remodeling: contribution to trophoblast invasion and placental development. J Immunol. (2010) 185:4420-9. doi: 10.4049/jimmunol.0903215

73. Mohlin FC, Mercier E, Fremeaux-Bacchi V, Liszewski MK, Atkinson JP, Gris JC, et al. Analysis of genes coding for CD46, CD55, and C4b-binding protein in patients with idiopathic, recurrent, spontaneous pregnancy loss. Eur J Immunol. (2013) 43:1617-29. doi: 10.1002/eji.201243196 
74. Asif A, Nayer A, Haas CS. Atypical hemolytic uremic syndrome in the setting of complement-amplifying conditions: case reports and a review of the evidence for treatment with eculizumab. J Nephrol. (2017) 30:347-62. doi: 10.1007/s40620-016-0357-7

75. Alrahmani L, Willrich MAV. The complement alternative pathway and preeclampsia. Curr Hypertens Rep. (2018) 19:87. doi: 10.1007/s11906-0180836-4

76. Sabau L, Terriou L, Provot F, Fourrier F, Roumier C, Caron C, et al. Are there any additional mechanisms for haemolysis in HELLP syndrome. Thromb Res. (2016) 142:40-3. doi: 10.1016/j.thromres.2016.03.014

77. Fakhouri F, Jablonski M, Lepercq J, Blouin J, Benachi A, Hourmant M, et al. Factor $\mathrm{H}$, membrane cofactor protein and Factor I mutations in patients with HELLP syndrome. Blood. (2008) 112:4242-545. doi: 10.1182/blood-2008-03144691

78. Vaught AJ, Braunstein EM, Jasem J, Yuan X, Makhlin I, Eloundou S, et al. Germline mutations in the alternative pathway of complement predispose to HELLP syndrome. JCI Insight. (2018) 3:0-13. doi: 10.1172/jci.insight.99128

79. Yonekura Collier A, Zsengeller Z, Pernicone E, Salahuddin S, Khankin EV, Karumanchi SA. Placental sFLT1 is associated with complement activation and syncytiotrophoblast damage in preeclampsia. Hypertens Pregnancy. (2019) 38:193-9. doi: 10.1080/10641955.2019.1640725

80. Burwick RM, Fichorova RN, Dawood HY, Yamamoto HS, Feinberg BB. Urinary excretion of C5b-9 in severe preeclampsia tipping the balance of complement activation in pregnancy. Hypertension. (2013) 62:1040-5. doi: 10.1161/HYPERTENSIONAHA.113.01420

81. Elabd H, Elkholi M, Steinberg L, Acharya A. Eculizumab, a novel potential treatment for acute kidney injury associated with preeclampsia/HELLP syndrome. BMJ Case Rep. (2019) 12:e228709. doi: 10.1136/bcr-2018-228709

82. Crovetto F, Borsa N, Acaia B, Nishimura C, Frees K, Smith RJH, et al. The genetics of the alternative pathway of complement in the pathogenesis of HELLP syndrome. J Matern Neonatal Med. (2012) 25:2322-5. doi: 10.3109/ 14767058.2012.694923

83. Ari E, Yilmaz Y, Gul A, Alahdab YO, Kedrah AE, Macunluoglu B, et al. Human serum complement $\mathrm{c} 3$ and factor $\mathrm{h}$ in the syndrome of hemolysis, elevated liver enzymes, and low platelet count. Am J Reprod Immunol. (2009) 62:238-42. doi: 10.1111/j.1600-0897.2009.00731.x

84. Vivier E, Tomasello E, Baratin M, Walzer T, Ugolini S. Functions of natural killer cells. Nat Immunol. (2008) 9:503-10. doi: 10.1038/ni1582

85. Bryceson YT, Chiang SCC, Darmanin S, Fauriat C, Schlums H, Theorell J, et al. Molecular mechanisms of natural killer cell activation. J Innate Immun. (2011) 3:216-26. doi: 10.1159/000325265

86. Smyth MJ, Zachariae CC, Norihisa Y, Ortaldo JR, Hishinuma A, Matsushimat KIL-. 8 gene expression and production in human peripheral blood lymphocyte subsets. J Immunol. (1991) 146:3815-23.

87. Warren HS, Kinnear BF, Phillips JH, Lanier LL. Production of IL-5 by human NK cells and regulation of IL-5 secretion by IL-4, IL-10, and IL-12. J Immunol. (1995) 154:5144-52.

88. Faas MM, de Vos P. Uterine NK cells and macrophages in pregnancy. Placenta. (2017) 56:44-52. doi: 10.1016/j.placenta.2017.03.001

89. Cristiani CM, Palella E, Sottile R, Tallerico R, Garofalo C, Carbone E. Human NK cell subsets in pregnancy and disease: toward a new biological complexity. Front Immunol. (2016) 7:1-7. doi: 10.3389/fimmu.2016.00656

90. Moffett-King A. Natural killer cells and pregnancy. Nat Rev Immunol. (2002) 2:656-63. doi: 10.1038/nri886

91. Gamliel M, Goldman-Wohl D, Isaacson B, Gur C, Stein N, Yamin R, et al. Trained memory of human uterine NK cells enhances their function in subsequent pregnancies. Immunity. (2018) 48:951-62. doi: 10.1016/j. immuni.2018.03.030

92. Meyer N, Schüler T, Zenclussen AC. Simultaneous ablation of uterine natural killer cells and uterine mast cells in mice leads to poor vascularization and abnormal doppler measurements that compromise fetal well-being. Front Immunol. (2018) 8:1913. doi: 10.3389/fimmu.2017.01913

93. Chapman LM, Aggrey AA, Field DJ, Srivastava K, Ture S, Yui K, et al. Platelets present antigen in the context of MHC Class I. J Immunol. (2012) 189:916-23. doi: 10.4049/jimmunol.1200580

94. Sadallah S, Schmied L, Eken C, Charoudeh HN, Amicarella F, Schifferli JA. Platelet-derived ectosomes reduce NK cell function. J Immunol. (2016) 197:1663-71. doi: 10.4049/jimmunol.1502658
95. von Adrian UH, Mackay CR. T-cell function and migration; two sides of the same coin. N Engl J Med. (2000) 343:1020-34. doi: 10.1056/ nejm200010053431407

96. Chames MC, Haddad B, Barton JR, Livingston JC, Sibai BM, Suarez Rightmire D, et al. Subsequent pregnancy outcome in women with a history of HELLP syndrome at $=28$ weeks of gestation. Am J Obstet Gynecol. (2003) 188:1504-8. doi: $10.1067 / \mathrm{mob} .2003 .383$

97. Malmström O, Morken NH. HELLP syndrome, risk factors in first and second pregnancy: a population-based cohort study. Acta Obstet Gynecol Scand. (2018) 97:709-16. doi: 10.1111/aogs.13322

98. Zimmerer JM, Pham TA, Wright CL, Tobin KJ, Sanghavi PB, Elzein SM, et al. Alloprimed CD8+ T cells regulate alloantibody and eliminate alloprimed B cells through perforin- and FasL-dependent mechanisms. Am J Transpl. (2014) 14:295-304. doi: 10.1111/ajt.12565

99. Arck PC, Hecher K. Fetomaternal immune cross-talk and its consequences for maternal and offspring's health. Nat Med. (2013) 19:548-56. doi: 10.1038/ nm. 3160

100. Saito S, Nakashima A, Shima T, Ito M. Th1/Th2/Th17 and regulatory T-cell paradigm in pregnancy. Am J Reprod Immunol. (2010) 63:601-10. doi: 10. 1111/j.1600-0897.2010.00852.x

101. Graca L, Cobbold SP, Waldmann H. Identification of regulatory T cells in tolerated allografts. J Exp Med. (2002) 195:1641-6. doi: 10.1084/jem. 20012097

102. Zenclussen AC, Gerlof K, Zenclussen ML, Sollwedel A, Bertoja AZ, Ritter $\mathrm{T}$, et al. Abnormal T-cell reactivity against paternal antigens in spontaneous abortion. Am J Pathol. (2005) 166:811-22. doi: 10.1016/s0002-9440(10) 62302-4

103. Jasper MJ, Tremellen KP, Robertson SA. Primary unexplained infertility is associated with reduced expression of the T-regulatory cell transcription factor Foxp3 in endometrial tissue. Mol Hum Reprod. (2006) 12:301-8. doi: 10.1093/molehr/gal032

104. Winger EE, Reed JL. Low circulating CD $4+\mathrm{CD} 25+$ Foxp $3+$ T regulatory cell levels predict miscarriage risk in newly pregnant women with a history of failure. Am J Reprod Immunol. (2011) 66:320-8. doi: 10.1111/j.1600-0897. 2011.00992.x

105. Prins JR, Boelens HM, Heimweg J, Van Der Heide S, Dubois AE, Van Oosterhout AJ, et al. Preeclampsia is associated with lower percentages of regulatory T cells in maternal blood. Hypertens Pregnancy. (2009) 28:300-11. doi: 10.1080/10641950802601237

106. Teles A, Schumacher A, Kühnle MC, Linzke N, Thuere C, Reichardt P, et al. Control of uterine microenvironment by Foxp3+ cells facilitates embryo implantation. Front Immunol. (2013) 4:1-12. doi: 10.3389/fimmu. 2013.00158

107. Care AS, Bourque SL, Morton JS, Hjartarson EP, Robertson SA, Davidge $S T$. Reduction in regulatory $t$ cells in early pregnancy causes uterine artery dysfunction in mice. Hypertension. (2018) 72:177-87. doi: 10.1161/ HYPERTENSIONAHA.118.10858

108. Sasaki Y, Darmochwal-Kolarz D, Suzuki D, Sakai M, Ito M, Shima T, et al. Proportion of peripheral blood and decidual CD4 + CD25 bright regulatory T cells in pre-eclampsia. Clin Exp Immunol. (2007) 149:139-45. doi: 10.1111/ j.1365-2249.2007.03397.x

109. Toldi G, Švec P, Vásárhelyi B, Mészáros G, Rigó J, Tulassay T, et al. Decreased number of FoxP3+ regulatory $\mathrm{T}$ cells in preeclampsia. Acta Obstet Gynecol Scand. (2008) 87:1229-33. doi: 10.1080/0001634080238 9470

110. Darmochwal-Kolarz D, Kludka-Sternik M, Tabarkiewicz J, Kolarz B, Rolinski J, Leszczynska-Gorzelak B, et al. The predominance of Th17 lymphocytes and decreased number and function of Treg cells in preeclampsia. J Reprod Immunol. (2012) 93:75-81. doi: 10.1016/j.jri.2012. 01.006

111. Paeschke S, Chen F, Horn N, Fotopoulou C, Zambon-Bertoja A, Sollwedel A, et al. Pre-eclampsia is not associated with changes in the levels of regulatory $\mathrm{T}$ cells in peripheral blood. Am J Reprod Immunol. (2005) 54:384-9. doi: 10.1111/j.1600-0897.2005.00334.x

112. Hu D, Chen Y, Zhang W, Wang H, Wang Z, Dong M. Alteration of peripheral CD4+CD25+ regulatory $\mathrm{T}$ lymphocytes in pregnancy and preeclampsia. Acta Obstet Gynecol Scand. (2008) 87:190-4. doi: 10.1080/ 00016340701823991 
113. Steinborn A, Haensch GM, Mahnke K, Schmitt E, Toermer A, Meuer S, et al. Distinct subsets of regulatory $\mathrm{T}$ cells during pregnancy: is the imbalance of these subsets involved in the pathogenesis of preeclampsia? Clin Immunol. (2008) 129:401-12. doi: 10.1016/j.clim.2008.07.032

114. Steinborn A, Schmitt E, Kisielewicz A, Rechenberg S, Seissler N, Mahnke $\mathrm{K}$, et al. Pregnancy-associated diseases are characterized by the composition of the systemic regulatory $\mathrm{T}$ cell ( $\mathrm{T}$ reg) pool with distinct subsets of $\mathrm{T}$ regs. Clin Exp Immunol. (2012) 167:84-98. doi: 10.1111/j.1365-2249.2011. 04493.x

115. Wagner MI, Jöst M, Spratte J, Schaier M, Mahnke K, Meuer S, et al. Differentiation of ICOS+ and ICOS- recent thymic emigrant regulatory T cells (RTE Tregs) during normal pregnancy, pre-eclampsia and HELLP syndrome. Clin Exp Immunol. (2016) 183:129-42. doi: 10.1111/cei.12693

116. Wallace K, Morris R, Kyle PB, Cornelius D, Darby M, Scott J, et al. Hypertension, inflammation and $\mathrm{T}$ lymphocytes are increased in a rat model of HELLP syndrome. Hypertens Pregnancy. (2014) 33:41-54. doi: 10.3109/ 10641955.2013.835820.Hypertension

117. Morris R, Spencer SK, Kyle PB, Williams JM, Harris A, Owens MY, et al. Hypertension in an animal model of HELLP syndrome is associated with activation of endothelin 1. Reprod Sci. (2016) 23:42-50. doi: 10.1177/ 1933719115592707

118. Bean C, Spencer SK, Bowles T, Kyle PB, Williams JM, Gibbens J, et al. Inhibition of T-cell activation attenuates hypertension, TNF $\alpha$, IL-17, and blood-brain barrier permeability in pregnant rats with angiogenic imbalance. Am J Reprod Immunol. (2016) 76:272-9. doi: 10.1111/aji.12547

119. Strand S, Strand D, Seufert R, Mann A, Lotz J, Blessing M, et al. Placenta-derived CD95 ligand causes liver damage in hemolysis, elevated liver enzymes, and low platelet count syndrome. Gastroenterology. (2004) 126:849-58. doi: 10.1053/j.gastro.2003.11.054

120. Prusac IK, Zekic Tomas S, Roje D. Apoptosis, proliferation and Fas ligand expression in placental trophoblast from pregnancies complicated by HELLP syndrome or pre-eclampsia. Acta Obstet Gynecol Scand. (2011) 90:1157-63. doi: 10.1111/j.1600-0412.2011.01152.x

121. Gibbens J, Morris R, Bowles T, Spencer SK, Wallace K. Dysregulation of the Fas/FasL system in an experimental animal model of HELLP syndrome. Pregnancy Hypertens. (2017) 8:26-30. doi: 10.1016/j.preghy.2017.02.004

122. Suzuki I, Fink PJ. The dual functions of Fas ligand in the regulation of peripheral CD8+ and CD4+ T cells. Proc Natl Acad Sci USA. (2000) 97:170712. doi: 10.1073 /pnas.97.4.1707

123. Paulsen M, Valentin S, Mathew B, Adam-Klages S, Bertsch U, Lavrik I, et al. Modulation of CD4+ T-cell activation by CD95 co-stimulation. Cell Death Differ. (2011) 18:619-31. doi: 10.1038/cdd.2010.134

124. Fettke F, Schumacher A, Costa SD, Zenclussen AC. B cells: the old new players in reproductive immunology. Front Immunol. (2014) 5:1-10. doi: 10.3389/fimmu.2014.00285

125. Muzzio D, Zenclussen AC, Jensen F. The role of B cells in pregnancy: the good and the bad. Am J Reprod Immunol. (2013) 69:408-12. doi: 10.1111/aji.12079

126. Lund FE. Cytokine-producing B lymphocytes-key regulators of immunity. Curr Opin Immunol. (2008) 20:332-8. doi: 10.1016/j.coi.2008.03.003

127. Rosser EC, Mauri C. Regulatory B cells: origin, phenotype, and function. Immunity. (2015) 42:607-12. doi: 10.1016/j.immuni.2015.04.005

128. Shen P, Roch T, Lampropoulou V, O'Connor RA, Stervbo U, Hilgenberg E, et al. IL-35-producing B cells are critical regulators of immunity during autoimmune and infectious diseases. Nature. (2014) 507:366-70. doi: 10. 1038/nature12979

129. Muzzio DO, Soldati R, Ehrhardt J, Utpatel K, Evert M, Zenclussen AC, et al. Cell development undergoes profound modifications and adaptations during pregnancy in micel. Biol Reprod. (2014) 91:1-11. doi: 10.1095/biolreprod. 114.122366

130. Lima J, Martins C, Leandro MJ, Nunes G, Sousa MJ, Branco JC, et al. Characterization of $B$ cells in healthy pregnant women from late pregnancy to post-partum: a prospective observational study. BMC Pregnancy Childbirth. (2016) 16:1-13. doi: 10.1186/s12884-016-0927-7

131. Feyaerts D, Benner M, Van Cranenbroek B, Van Der Heijden OWH, Joosten I, Van Der Molen RG. Human uterine lymphocytes acquire a more experienced and tolerogenic phenotype during pregnancy. Sci Rep. (2017) 7:1-10. doi: 10.1038/s41598-017-03191-0
132. Tufano A, Coppola A, Maruotti GM, Martinelli P, Cerbone AM, Di Minno GH. ELLP syndrome and its relation with the antiphospholipid syndrome. Blood Transfus. (2014) 12:114-8. doi: 10.2450/2013.0154-13

133. Le Thi Thuong D, Tieulié N, Costedoat N, Andreu MR, Wechsler B, VauthierBrouzes D, et al. The HELLP syndrome in the antiphospholipid syndrome: retrospective study of 16 in 15 women. Ann Rheum Dis. (2005) 64:273-8. doi: 10.1136/ard.2003.019000

134. Pourrat O, Coudroy R, Pierre F. Differentiation between severe HELLP syndrome and thrombotic microangiopathy, thrombotic thrombocytopenic purpura and other imitators. Eur J Obstet Gynecol Reprod Biol. (2015) 189:68-72. doi: 10.1016/j.ejogrb.2015.03.017

135. Triggianese P, Perricone C, Perricone R, De Carolis CH. ELLP. syndrome: a complication or a new autoimmune syndrome? Reumatologia. (2014) 52:377-83. doi: 10.5114/reum.2014.47231

136. Gleicher N. Autoantibodies in normal and abnormal pregnancy. Am J Reprod Immunol. (1992) 28:269-73. doi: 10.1111/j.1600-0897.1992.tb00812.x

137. Marzusch K, Dietl J, Korte K, Schnaidt M. Thrombocytopenia in the HELLP syndrome is not due to platelet-associated IgG (PAIgG). Eur J Obstet Gynecol Reprod Biol. (1992) 45:107-12. doi: 10.1016/0028-2243(92)90225-N

138. Weitgasser R, Spitzer D, Karting I, Zajc M, Staudach A, Sandhofer F. Association of HELLP syndrome with autoimmune antibodies and glucose intolerance. Diabetes Care. (2000) 23:786-90. doi: 10.2337/diacare.23.6.786

139. Jensen F, Wallukat G, Herse F, Budner O, El-Mousleh T, Costa SD, et al. CD19+CD5+ cells as indicators of preeclampsia. Hypertension. (2012) 59:861-8. doi: 10.1161/HYPERTENSIONAHA.111.188276

140. Bu S, Wang Y, Sun S, Zheng Y, Jin Z, Zhi J. Role and mechanism of AT1AA in the pathogenesis of HELLP syndrome. Sci Rep. (2018) 8:1-9. doi: 10.1038/s41598-017-18553-x

141. Fischer T, Wallukat G, Schneider MP, Schlembach D, Munz W, Homuth V. HELLP syndrome in the 18th week of gestation in association with elevated angiotensin AT 1 -receptor autoantibodies. Eur J Obstet Gynecol Reprod Biol. (2001) 97:255-7. doi: 10.1016/S0301-2115(00)00534-0

142. Venkatesha S, Toporsian M, Lam C, Hanai J, Mammoto T, Kim YM, et al. Soluble endoglin contributes to the pathogenesis of preeclampsia. Nat Med. (2006) 12:642-9. doi: 10.1038/nm1429

143. Zhou CC, Zhang Y, Irani RA, Zhang H, Mi T, Popek EJ, et al. Angiotensin receptor agonistic autoantibodies induce pre-eclampsia in pregnant mice. Nat Med. (2008) 14:855-62. doi: 10.1038/nm.1856

144. Tal R, Shaish A, Barshack I, Polak-Charcon S, Afek A, Volkov A, et al. Effects of hypoxia-inducible factor- $1 \alpha$ overexpression in pregnant mice: possible implications for preeclampsia and intrauterine growth restriction. Am J Pathol. (2010) 177:2950-62. doi: 10.2353/ajpath.2010.090800

145. Oe Y, Ko M, Fushima T, Sato E, Karumanchi SA, Sato H, et al. Hepatic dysfunction and thrombocytopenia induced by excess sFlt1 in mice lacking endothelial nitric oxide synthase. Sci Rep. (2018) 8:1-10. doi: 10.1038/s41598017-18260-7

146. Isler CM, Bennett WA, Rinewalt AN, Cockrell KL, Martin JN, Morrison JC, et al. Evaluation of a rat model of preeclampsia for HELLP syndrome characteristics. J Soc Gynecol Investig. (2003) 10:151-3. doi: 10.1016/S10715576(03)00009-1

147. Faas M, Schuiling G, Baller J, Visscher C, Bakker W. A new model for human preeclampsia. Am J Obstet Gynecol. (1994) 171:158-64. doi: 10.1016/00029378(94)90463-4

148. Mao M, Chen C. Corticosteroid therapy for management of hemolysis, elevated liver enzymes, and low platelet count (HELLP) syndrome: a metaanalysis. Med Sci Monit. (2015) 21:3777-83. doi: 10.12659/MSM.895220

Conflict of Interest: The authors declare that the research was conducted in the absence of any commercial or financial relationships that could be construed as a potential conflict of interest.

Copyright (c) 2020 Stojanovska and Zenclussen. This is an open-access article distributed under the terms of the Creative Commons Attribution License (CC BY). The use, distribution or reproduction in other forums is permitted, provided the original author(s) and the copyright owner(s) are credited and that the original publication in this journal is cited, in accordance with accepted academic practice. No use, distribution or reproduction is permitted which does not comply with these terms. 